\title{
RANCANGAN KONSEP DAN PRINSIP EKOLOGI UNTUK BAHAN AJAR PROGRAM S1 BIOLOGI PADA SISTEM PENDIDIKAN TERBUKA DAN JARAK JAUH
}

\author{
Yuni Tri Hewindati \\ Universitas Terbuka (UT) Jakarta, Indonesia \\ Email: hewindati@ecampus.ut.ac.id \\ Received: 2021-02-15; Accepted: 2021-02-30; Published: 2021-03-10
}

\begin{abstract}
Abstrak
Matakuliah ekologi pada Fakultas Sains dan Teknologi-Universitas Terbuka, merupakan matakuliah dasar yang ditempuh oleh mahasiswa dari dua program studi yaitu Program Studi S1-Biologi dan Program Studi S1-Perencanaan Wilayah dan Kota. Sebagai program studi yang menggunakan sistem pembelajarannya secara jarak jauh, buku materi pokok (BMP) merupakan bahan ajar (BA) utama yang dirancang agar selfcontained dan self-instructional untuk dapat dipelajari secara mandiri oleh mahasiswa. Penyampaian materi ekologi kedalam BA tercetak merupakan tantangan tersendiri, terutama dalam merancang agar materi aktual, valid, sistematis, menarik, dan sesuai dengan karakteristik mahasiswa. Tulisan ini melaporkan hasil studi yang bertujuan untuk merancang bahan ajar mata kuliah Ekologi berdasarkan analisis pakar terhadap materi bahan ajar mata kuliah ekologi dan analisis aspirasi mahasiswa yang mengambil matakuliah ekologi yang digunakan sekarang. Hasil analisis pakar menunjukkan bahwa materi yang disampaikan pada bahan ajar eksisting secara konsep sudah benar dan valid. Namun demikian, sebagian besar $(80 \%)$ materi masih berupa teks dan masih perlu diperkaya dengan ilustrasi dan berbagai contoh terkait kasus serta implementasi konsep di lapangan. Demikian juga, sistematika penulisan perlu disusun ulang dengan menekankan dan memberikan gambaran tentang konservasi dan pengelolaan kawasan untuk menunjang pembangunan berkelanjutan. Sejalan dengan pendapat pakar, data dari mahasiswa memperlihatkan bahwa sebagian besar mahasiswa menghendaki lebih banyak topik yang menunjang pekerjaan mereka, yaitu keanekaragaman hayati dan konservasi ekosistem untuk menunjang pembangunan yang berkelanjutan (41\%). Sementara untuk penggunaan media penunjang bahan ajar, sebanyak $47 \%$ mahasiswa menginginkan materi diperkaya dengan video.
\end{abstract}

Keywords: materi ekologi, karakteristik mahasiswa, analisis Instruksional

\section{PENDAHULUAN}

Universitas Terbuka (UT), sebagai perguruan tinggi yang menyelenggarakan sistem pendidikannya secara terbuka dan jarak jauh mengutamakan fleksibilitas dalam menyediakan akses terhadap masyarakat yang ingin belajar pada jenjang pendidikan tinggi. Oleh karena itu dengan menerapkan konsep "terbuka", memberikan kesempatan kepada masyarakat untuk dapat mengakses UT tanpa mengenal restriksi umur, lama studi, dsb. Sementara dengan prinsip jarak jauh memungkinkan mahasiswa dimanapun berada (tempat tinggal), untuk dapat mengakses belajar di UT dengan menggunakan berbagai media yang disesuaikan dengan kemampuan sarana dan prasarana yang dimiliki oleh mahasiswa. Hal ini merupakan tantangan bagi UT mengingat Indonesia memiliki wilayah geografi, budaya, dan juga ketersediaan sarana dan prasarana sumber belajar yang sangat beragam. 
Karena prinsip pembelajaran UT adalah belajar mandiri, maka bahan ajar (BA) merupakan sumber belajar yang dirancang agar self-contained dan self-instructional untuk dapat dipelajari secara mandiri oleh mahasiswa. Salah satu BA adalah BA mata kuliah Ekologi (BIOL4215) pada Fakultas Sains dan Teknologi (FST) yang merupakan matakuliah wajib di Program Studi S1-Biologi dan Program Studi S1-Perencanaan Wilayah dan Kota (PWK). Matakuliah ini memberikan konsep dan prinsip dasar pengetahuan tentang ekologi serta penerapannya di lingkungan sekitar. Untuk melengkapi kompetensi keterampilan yang diharapkan dapat dikuasai mahasiswa, matakuliah Ekologi dilengkapi dengan kegiatan praktikum. Praktikum dilakukan di laboratorium melalui kerjasama dengan universitas dimana mahasiswa berada. Untuk membekali mahasiswa terhadap materi praktikum, kegiatan praktikum juga dilengkapi dengan materi dry lab yang berisi simulasi praktikum di lapangan, prosedur pelaksanaan praktikum, serta penggunaan alat laboratorium yang dapat dipelajari mahasiswa sebelum melaksanakan praktikum di laboratorium/lapangan.

Mengingat matakuliah Ekologi berisi konsep dasar untuk diterapkan di lingkungan, maka materi yang diberikan selain harus sesuai dengan prinsip-prinsip ekologi dan ilmu pengetahuan lingkungan yang perubahannya sangat cepat, juga harus dapat memberikan pengetahuan yang dibutuhkan mahasiswa dalam dunia kerja/profesi yang digelutinya. Namun demikian, pengembangan BA mata kuliah Ekologi yang ada saat ini belum didasarkan atas kajian terhadap aspirasi mahasiswa serta perkembangan materi ekologi dimasa depan. Artikel ini menyajikan hasil studi yang menganalisis aspirasi mahasiswa yang mengambil matakuliah ekologi, yaitu yang terdaftar pada Program Studi S1-Biologi dan Program S1-PWK serta pendapat pakar terkait kesesuaian materi ekologi sehingga dapat dijadikan acuan dan inspirasi untuk memutakhirkan bahan ajar ekologi di FST UT.

\section{METODE PENELITIAN}

Penelitian ini adalah penelitian eksplorasi dengan subjek penelitian adalah bahan ajar matakuliah Ekologi. Metode pengumpulan data dilakukan dengan dua cara utama, yaitu: (1) analisis oleh pakar terhadap substansi bahan ajar ekologi eksisting dan (2) survey aspirasi mahasiswa yang mengambil matakuliah ekologi. Untuk analisis oleh pakar dilakukan melalui wawancara terstruktur secara langsung terkait validitas substansi materi, kedalaman, kesesuaian materi dengan jenjang $\mathrm{S} 1$, dan tampilan bahan ajar agar agar mudah dipelajari oleh mahasiswa. Sementara untuk karakteristik mahasiswa dilakukan dengan memberikan kuesioner kepada 40 mahasiswa yang mengikuti tutorial (online), dimana sebanyak 13 orang mengembalikan. Pertanyaan kuesioner untuk mahasiswa terkait latar belakang, pekerjaan, kompetensi yang diharapkan dari materi modul, media yang digunakan untuk mempermudah mempelajari modul, serta perangkat yang digunakan untuk mengakses modul secara online. Kuesioner diberikan kepada mahasiswa yang mengikuti tutorial online, dengan harapan bahwa matakuliah ini ke depannya akan dikembangkan dalam bentuk digital yang hanya dapat diakses oleh mahasiswa yang memiliki sarana akses terhadap internet. Dari hasil analisis pakar dan kuesioner mahasiswa kemudian dirumuskan CP dan tujuan Instruksional Khusus (TIK) yang didiskusikan dalam bentuk FGD bersama pakar materi, pakar media, dan mahasiswa. 


\section{HASIL PENELITIAN DAN PEMBAHASAN}

\section{A. Analisis Substansi Pakar}

Ekologi sebagai salah satu cabang ilmu biologi merupakan matakuliah dasar yang sangat erat kaitannya dengan alam dan lingkungan tempat organisme hidup di muka bumi ini. Oleh karena itu matakuliah ini digunakan oleh program studi lain yang terkait dengan ilmu terapan lingkungan hidup. Peran ekologi yang memberikan pengetahuan tentang konsep dan prinsip dasar ilmu biologi sangat penting dalam memahami fenomena yang terjadi di lingkungan. Dinamika perubahan yang cepat di lingkungan tentunya akan berpengaruh terhadap implementasi dari konsep-konsep biologi yang dipelajari.

Hasil analisis pakar materi menunjukkan bahwa secara substansi, ruang lingkup dan konsep yang terdapat pada BA eksisting matakuliah Ekologi (BIOL4215) untuk mahasiswa Biologi S1-UT sudah benar dan valid untuk ruang lingkup substansi matakuliah BIOL4215 eksisting. Ruang lingkup kedalaman dan isi modul juga telah mencakup aspek-aspek ekologi yang meliputi teori dan konsep ekologi yang menjelaskan hubungan antara invidu dalam spesies, antar spesies, populasi, dan komunitas di dalam ekosistem dengan memberikan contoh ekosistem terrestrial maupun perairan. Pada BA ini disampaikan juga tentang unsur-unsur pembatas dan pendukung yang mengontrol organisme dalam konteks ekologi. Selanjutnya, pada akhir BA disampaikan kegiatan belajar tentang penerapan ekologi di dalam ekosistem dan konsep berkelanjutan, sehingga secara utuh materi BA sudah cukup baik sebagai BA untuk bidang studi mahasiswa jenjang S1. Adapun materi ekologi bahan ajar eksisting mencakup beberapa kompetensi sebagai berikut.

a. Pengertian, Ruang Lingkup Ekologi, dan Ekosistem

b. Energi dalam Ekosistem

c. Siklus Biogeokimiawi

d. Faktor Pembatas

e. Populasi

f. Konsep dan Klasifikasi Komunitas Individu dalam Ekosistem

g. Perkembangan Ekosistem

h. Penerapan Ekologi dalam Pembangunan yang Berkelanjutan

Namun demikian, ada beberapa isu penting yang perlu mendapat porsi di dalam BA yang saat ini belum tertuang secara cukup memadai, khususnya terkait contoh dan penerapan setiap konsep ekologi serta keterkaitan ekologi sebagai ilmu yang multidisipliner dengan ilmu lainnya. Sebagai ilmu yang mempelajari "rumah tangga" organisme, maka sebelum mempelajari ekologi perlu ditambahkan tentang pengenalan bagaimana memahami cara kerja alam sehingga unsur-unsur geosfer (atmosfer, litosfer, biosfer, hidrosfer, dan antosfer) yang sangat berpengaruh terhadap kehidupan di permukaan bumi juga perlu diperkenalkan. Hal ini agar mahasiswa mengetahui secara mendasar tentang ilmu ekologi sebagai instrumen untuk memahami cara kerja dari alam yang rumit namun teratur tersebut.

Peran ekologi adalah mempertanyakan, menyelidiki, dan memahami bagaimana alam bekerja secara mendasar. Selain itu, ekologi juga menjelaskan keberadaan makhluk hidup dan kebutuhannya dalam sistem kehidupan yang berbentuk habitat sebagai rumah dan tempat tinggalnya. Oleh karena itu, 
memberikan pemahaman habitat kepada mahasiswa di awal pembelajaran perlu diperdalam, termasuk memperkenalkan "mapping habitat method", baik pemetaan habitat terrestrial, pemetaan habitat perairan, termasuk observasi satelit yang saat ini sudah berkembang dengan pesat perlu diberikan. Disamping itu, gambaran umum sebelum masuk ke konsep yang lebih dalam terkait "habitat complexity dan habitat quality" juga sangat penting agar mahasiswa mampu memahami pentingnya habitat dalam studi ekologi. Pemahaman tersebut akan mempermudah mahasiswa memahami semua yang terjadi di dalam habitat, seperti perubahan habitat sebagai tempat hidup organisme, interaksi mahluk hidup yang ada di dalamnya, bagaimana organisme dapat hidup bersama, bertahan, dan beradaptasi di lingkungan yang sama dengan spesies lain dengan berbagai perubahannya, serta berbagai konsep ekologi lainnya.

Perubahan ekosistem yang diakibatkan oleh berbagai aktivitas manusia merupakan unsur penting yang juga perlu disampaikan di dalam modul ekologi. Sebetulnya contoh-contoh dampak aktivitas manusia, seperti pencemaran udara dan pencemaran air sudah disampaikan pada modul eksisting (modul terakhir). Hal ini berkaitan dengan perubahan iklim dan kegiatan manusia sebagai salah satu aspek dari Sustainnable Development Goals (SDGs), yang menurut analisis pakar belum tercakup dalam BA. Selain perlu ditambahkan materi tentang SDGs, juga perlu disampaikan tentang pentingnya kita sebagai individu mengambil peran di dalam SDGs sekecil apapun peran tersebut, karena akan memiliki dampak besar terhadap SDGs.

Perkembangan dan perubahan lingkungan saat ini banyak dipengaruhi oleh perkembangan IPTEK dan TIK, yang pada akhirnya mempengaruhi pola hidup tidak hanya kebutuhan manusia tetapi juga kebutuhan sosial. Perkembangan ilmu yang sangat pesat terutama di bidang teknologi dalam rangka memenuhi keinginan manusia untuk beraktivitas lebih cepat dan efisien mengakibatkan manusia saat ini hanya berorientasi pada ekonomi. Berbagai issue tentang kerusakan lingkungan yang disebabkan oleh pembangunan yang tidak berkelanjutan juga perlu diberikan sebagai bahan pemikiran para mahasiswa dan aksi tindakan nyata dalam implementasinya di lapangan. Oleh karena itu sesuai pendapat pakar (Prof. Sudharto), belajar ekologi bukan hanya memahami dasar-dasar ekologi, tetapi juga ekologi manusia dan rekayasa lingkungan serta manajemen lingkungan, dan peran IPTEK dalam isu-isu ekologi. Sebagaimana diketahui bahwa IImu ekologi merupakan ilmu yang mendasari ilmu lingkungan, sehingga antara ekologi dan lingkungan tidak dapat dipisahkan. Hal ini diungkapkan oleh pakar Ekologi UNPAD. Dr. Teguh Husodo yang menyatakan "Materi Ekologi merupakan materi dasar yang perlu dikuasai oleh mahasiswa dari program studi biologi. Matakuliah ekologi menjadi cabang ilmu biologi yang bersifat komprehensif yang dapat menjelaskan hubungan atau interaksi antara mahluk hidup termasuk manusia sebagai pusat dengan lingkungannya". Hal senada juga diungkapkan oleh Prof. Dr. Sudharto, pakar Lingkungan yang menyatakan bahwa "ilmu biologi merupakan ilmu yang menjadi dasar dari ilmu lingkungan. Logika dari the natural world work banyak disumbang oleh ilmu ekologi". Pendapat kedua pakar ini selaras dengan pernyataan Withgott and Brennan (2007) yang menyebutkan bahwa ilmu lingkungan adalah 'the 
study of how the natural world works, how our environment afect us and how we affect our environment.'

Secara spesifik, analisis pakar menunjukkan bahwa BA eksisting: (1) masih sangat teoritis dimana $80 \%$ materi berisi uraian ekologi dasar yang sangat konseptual seperti halnya pembelajaran yang banyak dijumpai di bukuteks, (2) kurang memberikan contoh yang dapat digunakan untuk penerapan/implementasi prinsip ekologi secara kontekstual dalam kehidupan sehari-hari, (3) perlu pemutakhiran beberapa materi karena Ekologi merupakan ilmu yang dinamis dan berkembang dengan pesat mengikuti perubahan alam, dan (4) perlu penyajian dengan pendekatan multiidispliner dan interdispliner karena ilmu ekologi merupakan ilmu holistik yang sangat erat kaitannya dengan berbagai bidang ilmu lainnya.

\section{B. Analisis Aspirasi Mahasiswa}

\section{Substansi Materi Ekologi}

Bahan ajar sebagai sumber pembelajaran utama mahasiswa UT harus relevan, selain dengan keluasan dan kedalaman substansi keilmuannya tetapi juga dengan kebutuhan penggunanya. Mahasiswa merupakan pengguna utama BA, oleh karena itu pengembang BA perlu mengetahui karakteristik mahasiswa. Karakteristik mahasiswa yang perlu dipahami antara lain terkait latar belakang pekerjaan, aspek materi ekologi yang paling dibutuhkan untuk mendukung pekerjaan mereka, tempat mahasiswa belajar dan mengakses BA, serta perangkat yang dimiliki dan digunakan untuk mengakses pembelajaran secara online (karena BA disampaikan dalam tutorial yang diselenggarakan secara online). Berdasarkan database UT 2019, 70\% mahasiswa Biologi mengaku sudah bekerja. Mahasiswa yang mengembalikan kuesioner pada studi ini juga memiliki pekerjaan pada berbagai bidang seperti dapat dilihat pada Tabel 1 .

\section{Tabel 1}

latar belakang pekerjaan mahasiswa

\begin{tabular}{lc}
\hline \multicolumn{1}{c}{ Latar Belakang Mahasiswa } & Jumlah \\
\hline Perkarantinaan Tumbuhan/pertanian * & 2 \\
\hline Industri Farmasi/Farmasi * & 2 \\
\hline Asisten Riset * & 1 \\
\hline Laboran * & 2 \\
\hline Petani & 1 \\
\hline Pegawai BPN & 1 \\
\hline Kesehatan * & 1 \\
\hline Konsultan engineering & 1 \\
\hline Analis Udara & 1 \\
\hline ASN & 1 \\
\hline
\end{tabular}

Faktor latar belakang pekerjaan mahasiswa mempengaruhi harapan mahasiswa akan substansi materi ekologi yang ingin dipelajarinya, serta kedalamannya. Sebanyak $41 \%$ mahasiswa yang mengembalikan kuesioner menyatakan bahwa materi ekologi yang paling banyak diperlukan untuk pekerjaan mereka adalah substansi yang terkait dengan keanekaragaman hayati dan konservasi ekosistem. Lebih jauh, data menunjukkan bahwa 29\% mahasiswa menginginkan bahasan terkait kesadaran global terhadap lingkungan yang aman, 
sehat, dan keberlanjutan; 18\% mahasiswa menginginkan bahasan terkait etika lingkungan; dan 12\% mahasiswa menginginkan bahasan terkait isu ketahanan pangan. Secara khusus mahasiswa mengharapkan contoh-contoh permasalahan yang ada di lapangan untuk pendalaman pembahasan substansi tersebut. Pernyataan mahasiswa tentang topik dan substansi BA ini sejalan dengan pernyataan pakar yang juga menyatakan bahwa materi BA matakuliah ekologi eksisting perlu diperkaya dengan substansi terkait isu-isu yang berkembang di lapangan yang langsung terkait dengan permasalahan terkini.

\section{Media BA}

Pembelajaran di UT bertumpu pada pemberian materi melalui BA yang dirancang sebagai BA tercetak (buku) yang dikenal dengan sebutan BMP dan modul. Perancangan penyajian materi didasarkan pada format cetak, yaitu menggunakan teks dan gambar statis (termasuk foto). Seiring perkembangan teknologi, UT mengembangka materi pengayaan dalam beragam format multi media seperti video dan video interaktif. Namun materi pengayaan tersebut tidak terintegrasi dengan BA yang berupa BMP tercetak.

Matakuliah ekologi yang banyak berhubungan dengan alam dan lingkungan akan ideal disajikan dalam suatu paket BA multimedia yang terintegrasi untuk meningkatkan minat belajar dan pemahaman mahasiswa terhadap materi. Penggunaan multimedia akan melibatkan berbagai indera, dan dengan penggunaan sebanyak mungkin indera untuk berinteraksi dengan isi pembelajaran akan mengoptimalkan penguasaan materi pelajaran (Munir, 2010). Selain itu, multimedia juga dapat membantu menguatkan penjelasan berbagai konsep ekologi melalui contoh-contoh yang divisualisasikan dengan foto, gambar, animasi, video, dsb.

Namun demikian, dalam proses belajar setiap mahasiswa memiliki karakteristik dan gaya belajar yang berbeda. Oleh karena itu, pemilihan media harus tepat sesuai dengan karakteristik mahasiswa. Data menunjukkan bahwa seluruh mahasiswa yang mengembalikan kuesioner menginginkan BA multimedia untuk membantu proses belajar mereka. Sebagian besar mahasiswa menghendaki BA yang dilengkapi dengan video (47\%), diikuti dengan gambar/foto $(35 \%)$, animasi (12\%), dan audio (6\%).

Video dan gambar merupakan media yang paling disukai dan diinginkan mahasiswa, dimana keduanya melibatkan indera mata untuk menangkap informasi. Berbagai pengamatan, fenomena, dan kejadian alam akan lebih mudah dipahami jika melibatkan indera mata. Hal senada juga disampaikan oleh Munir (2010) bahwa alat indera yang paling banyak digunakan untuk memahami suatu pembelajaran adalah mata atau penglihatan yaitu sebesar $80 \%$. Berturut-turut indera telinga atau pendengaran sebesar $11 \%$, indera kulit atau peraba sebesar $1,5 \%$, indera lidah atau perasa sebesar $1 \%$, dan terakhir hidung atau penciuman sebesar $0,5 \%$.

Mengingat sebanyak 75\% mahasiswa sudah bekerja (SRS-UT, 2020), maka memperkaya konsep ekologi dengan menambahkan media berupa video untuk meningkatkan kompetensi mahasiswa tampaknya menjadi aspek yang sangat penting dalam proses pembelajaran mereka. Selain mengurangi kegiatan membaca setelah bekerja seharian, media audio visual dapat meningkatkan motivasi belajar karena melibatkan imaginasi (Arsyad, 2011). 
Namun demikian, keinginan mahasiswa untuk BA yang dilengkapi dengan media video ini tentu harus dipertimbangkan dengan seksama. BA harus dapat diakses oleh mahasiswa di mana pun mereka berada, sedangkan kondisi infrastruktur BA yang dikembangkan harus dapat diakses oleh seluruh mahasiswa di mana pun mereka berada. Mahasiswa yang ingin mengakses BA multimedia yang mengandung video memerlukan bandwith yang cukup dan lebih besar dari BA berbais teks dan gambar statis. Salah satu isu di Indonesia adalah belum meratanya ketersediaan jaringan internet, sehingga berpotensi menjadi kendala bagi mahasiswa yang berada di daerah tertentu yang jaringan internetnya belum tersedia atau belum terlalu baik. Oleh karena itu, pengembangan BA yang mengandung video harus dirancang agar tidak memberatkan bandwith mahasiswa. Salah satu cara adalah dengan memberikan link video yang sesuai dengan konsep ekologi pada setiap TIK, dengan memanfaatkan video yang ada pada sumber media open source di Internet, yang tersedia secara gratis. Selain memilih durasi yang tidak terlalu panjang, pemilihan video di situs open-source juga perlu mempertimbangkan kualitas yang valid, sesuai, dan menunjang kompetensi yang harus dikuasai.

\section{Analisis Instruksional Matakuliah Ekologi}

BA dikembangkan berdasarkan rumusan capaian pembelajaran matakuliah yang ditargetkan. Rumusan capaian pembelajaran (CPL) matakuliah Ekologi (BIOL4215) adalah "mahasiswa mampu menerapkan konsep dan prinsip Ekologi pada kehidupan sehari-hari dalam upaya pengelolaan lingkungan hidup“. CPL inilah yang merupakan tujuan instruksional umum (TIU) matakuliah. Berdasarkan hasil analisis pakar, rumusan capaian pembelajaran ini tampaknya masih relevan.

Namun demikian, walaupun substansi, konsep dan prinsip ekologi yang diharapkan dapat dikuasai oleh mahasiswa tidak terlalu jauh berbeda, beberapa ranah kognitif yang harus dikuasai perlu disesuaikan. Di UT, semua BA dikembangkan berdasarkan Rancangan Matakuliah (RMK) terkait. RMK ini berisi $\mathrm{CPL}$, daftar kompetensi antara yang harus dicapai agar CPL tersebut dapat dicapai di akhir pembelajaran matakuliah bersangkutan, serta peta kompetensi-kompetensi tersebut. Secara struktur, keseluruhan kompetensi-kompetensi antara yang harus dicapai itu dijabarkan dalam materi-materi pembelajaran secara moduler. Untuk matakuliah BIOL4215 yang berbobot 3 sks, maka materi dituangkan menjadi 9 modul dimana setiap modul dibagi lagi menjadi beberapa Kegiatan Belajar (KB). Setiap KB pada umumnya ditujukan untuk mencapai beberapa kompetensi antara yang spesifik yang disebut Tujuan Instruksional Khusus (TIK).

Berdasarkan pemetaan hasil analisis pakar dan aspirasi mahasiswa terhadap rancangan matakuliah eksisting tampak bahwa diperlukan perumusan ulang beberapa TIK yang ada disamping juga penggantian beberapa TIK pada setiap modul. Secara umum, jumlah TIK yang pada RMK eksisting adalah 45 berubah menjadi 58. Penambahan jumlah TIK ini untuk menindaklanjuti perlunya pendalaman materi pada beberapa topik. Disamping itu, perubahan juga terjadi pada jenjang kognitif yang harus dikuasai oleh mahasiswa. Pada RMK eksisting, kompetensi yang harus dicapai mahasiswa hanya pada jenjang kognitif rendah, yaitu pada kemampuan untuk 'menjelaskan' dan 'menggambarkan', yang 
keduanya merupakan tingkat kognitif $\mathrm{C} 2$ pada Taksonomi Bloom. Sedangkan pada RMK baru, jenjang kompetensi yang harus dikuasai mahasiswa hingga jenjang 'memberi contoh', 'mengklasifikasikan' dan 'menginterpretasikan' yang merupakan kemampuan jenjang penerapan (C3) dan analisis (C4) pada Taksonomi Bloom. Perbandingan jenjang kemampuan kognitif pada BA eksisting dan yang baru dapat dilihat pada Tabel 2.

Tabel 2

Perbedaan Jenjang Kognitif Modul Eksisting dengan Hasil Analisis

\begin{tabular}{lcc}
\hline \hline \multirow{2}{*}{ Ranah Kognitif } & \multicolumn{2}{c}{ Jumlah TIK (learning objectives) } \\
\cline { 2 - 3 } & Modul Eksisting & Hasil Analisis \\
\hline Mendefinisikan & 1 \\
\hline Menyebutkan & 44 & 2 \\
\hline Menjelaskan & & 45 \\
\hline Memberikan contoh & 1 & 1 \\
\hline Menggambarkan & & 2 \\
\hline Membedakan & & 1 \\
\hline Mengidentifikasi & & 1 \\
\hline Mengklasifikasikan & & 1 \\
\hline Menginterpretasikan & $\mathbf{4 5}$ & $\mathbf{5 8}$ \\
\hline \multicolumn{1}{c}{ Jumlah } &
\end{tabular}

Rumusan 58 TIK yang teridentifikasi adalah sebagai berikut.

1. Menjelaskan pengertian dan ruang lingkup ekologi

2. Menjelaskan bidang kajian ekologi dan hubungannya dengan bidang ilmu lainnya

3. Menjelaskan perkembangan ilmu ekologi dan penerapan ilmu ekologi pada berbagai bidang praktis;

4. Menjelaskan pendekatan metode penelitian pada bidang ekologi

5. Menjelaskan pengertian dan konsep habitat

6. Menjelaskan pengertian dan konsep terbentuknya relung ekologi (niche)

7. Membedakan habitat dengan relung ekologi

8. Menjelaskan pengertian, konsep, dan teori tentang faktor pembatas

9. Menjelaskan indikator ekologi dari berbagai aspek

10. Membedakan prinsip dari hukum minimum Liebig dan hukum toleransi Sherfold

11. Menjelaskan arti dari batas toleransi steno-euri

12 Mendefinisikan populasi

13 Mengidentifikasi berbagai karakteristik populasi

14 Menjelaskan pola distribusi intern dari individu

15 Menyebutkan faktor-faktor yang mempengaruhi pergerakan individu

16 Menjelaskan pertumbuhan dan regulasi pertumbuhan populasi

17 Menginterpretasikan tabel kehidupan dan kurva ketahanan hidup

18 Menjelaskan strategi pertahanan hidup $\mathrm{r}$ dan $\mathrm{K}$

19 Menjelaskan pengertian dan konsep evolusi

20 Menjelaskan proses evolusi pada tingkat populasi

21 Menjelaskan spesiasi dan peran manusia dalam penyebaran populasi

22 Menjelaskan peran manusia dalam penyebaran populasi

23 Menjelaskan pengertian dan sejarah, tujuan, dan tahapan domestikasi

24 Menjelaskan dampak domestikasi

25 Menjelaskan contoh spesias invasi 
26 Menjelaskan konsep dan klasifikasi komunitas

27 Menjelaskan karakteristik komunitas

28 Menyebutkan berbagai interaksi antar spesies (Interspesific Interaction) di dalam komunitas

29 Menjelaskan parameter analisis komunitas

30 Menjelaskan indeks keanekaragaman spesies dalam komunitas

31 Menjelaskan pengertian dan konsep ekosistem

32 Menjelaskan struktur dan komponen ekosistem

33 Menjelaskan faktor pengendali ekosistem

34 mengklasifikasikan berbagai Ekosistem berdasarkan IBSAP

35 Menjelaskan prinsip dan proses suksesi ekosistem

36 Membedakan prinsip suksesi primer dan suksesi sekunder

37 Membedakan ekosistem alami dan ekosistem buatan

38 Menjelaskan pengertian dan prinsip ekosistem pertanian

39 Menjelaskan faktor yang mempengaruhi perubahan/faktor pengendali pada ekosistem pertanian

40 Menjelaskan ekosistem perkotaan merupakan perubahan ekosistem perdesaan (rural ecosystem)

41 Menjelaskan berbagai faktor pengendali dalam perubahan dan perkembangan ekosistem buatan

42 Menjelaskan ruang lingkup, karakteristik, dan interaksi yang terjadi pada ekosistem perairan

43 Menjelaskan ruang lingkup, karakteristik, dan interaksi yang terjadi pada ekosistem daratan

44 Menjelaskan konsep homeostatis dan thermodinamika

45 Menjelaskan aliran energi, siklus materi, dan struktur tropik di dalam ekosistem

46 Menjelaskan efisiensi ekologi

47 Menjelaskan produktivitas primer dan sekunder, serta hasil panen

48 Menjelaskan berbagai metode pengukuran produktivitas primer

49 Menggambarkan pola dan tipe dasar siklus nitrogen, siklus fosfor, dan siklus sulfur, siklus karbondioksida, dan siklus hidrologi

50 Menjelaskan unsur hara bagi tanaman

51 Menggambarkan siklus hara di dalam ekosistem

52 Menjelaskan organisme yang terlibat dalam siklus hara

53 Menjelaskan pengertian pembangunan berkelanjutan

54 Menjelaskan sejarah dan konsep pembangunan berkelanjutan

55 Menjelaskan pengertian keberlanjutan dan keberlanjutan ekologis

56 Menjelaskan hubungan ekosistem, keanekaragaman spesies, dan layanan ekosistem

57 Menjelaskan pengertian dan penyebab kerusakan lingkungan,

58 Menjelaskan berbagai pencemaran lingkungan dan dampaknya terhadap lingkungan

Keseluruhan TIK ini kemudian dipetakan kembali untuk menerjemahkannya menjadi struktur bahan ajar yang moduler, yang terdiri dari sembilan modul (Gambar 1). Setiap kompetensi yang harus dikuasasi diberi nomor 1 sampai dengan 58, dan kompetensikompetensi yang terkait dikelompokkan menjadi setiap kotak yang menggambarkan 
modul tertentu. Kotak paling bawah menggambarkan kompetensi yang harus dikuasai terlebih dahulu oleh mahasiswa. Demikian seterusnya sampai kompetensi yang paling tinggi pada kotak yang paling atas. Setelah semua dipelajari oleh mahasiswa, mahasiswa diharapkan telah menguasai CPL Ekologi, yaitu "mampu menerapkan prinsip dan konsep ekologi pada kehidupan sehari-hari dalam upaya pengelolaan Lingkungan Hidup". Hasil pemetaan TIK yang telah dihasilkan ini dijadikan sebagai dasar untuk melakukan revisi BA matakuliah Ekologi. Demikian juga, BA ini akan dikembangkan secara terintegrasi dengan video, gambar, dan foto.

Peta Kompetensi

Ekologi/BIOL 4215/3 SKS

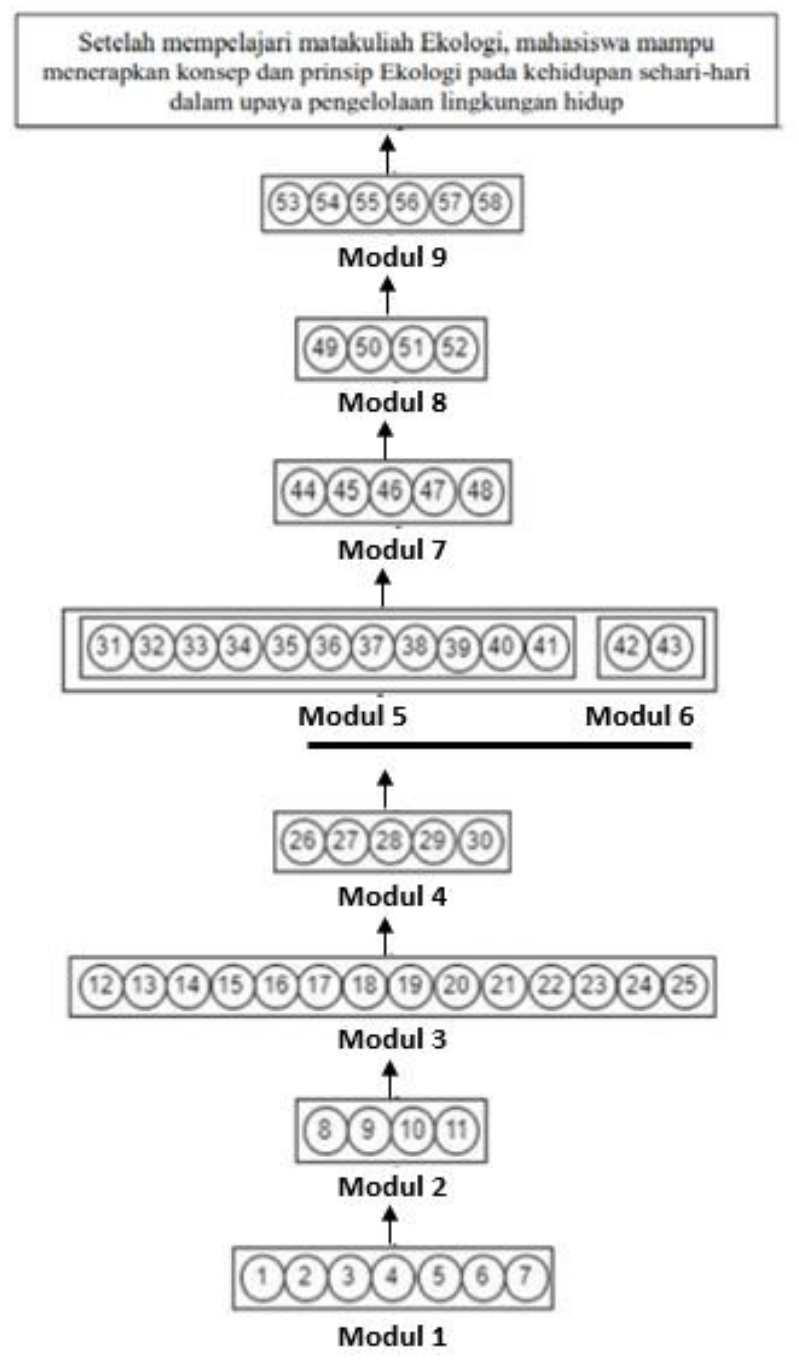

Gambar 1. Peta Kompetensi Matakuliah Ekologi

\section{KESIMPULAN}

BA Ekologi (BIOL4215) merupakan materi utama yang digunakan oleh mahasiswa program studi S1-Biologi dan S1-PWK. Capain pembelajaran yang harus dikuasai mahasiswa setelah menyelesaikan matakuliah ini adalah "mampu menerapkan konsep dan prinsip Ekologi pada kehidupan sehari-hari dalam upaya pengelolaan lingkungan hidup“. Oleh karena itu, mahasiswa perlu mendapatkan prinsip dan konsep ekologi dalam untuk memahami berbagai fenomena 
dan memecahkan permasalahan lingkungan. Sebagai perguruan tinggi yang menerapkan pembelajaran jarak jauh, materi pembelajaran harus dituangkan dalam suatu BA yang bersifat self-contained dan self-instructional agar dapat dipelajari secara mandiri oleh mahasiswa.

Hasil analisis pakar terhadap BA matakuliah Ekologi eksisting menunjukkan bahwa validitas substansi materi ekologi sudah cukup baik dan benar. Demikian pula materi yang disampaikan dinilai sudah cukup komprehensif untuk ilmu ekologi pada jenjang S1. Namun demikian, ada topik yang masih memerlukan pendalaman dan elaborasi agar lebih mudah dipelajari oleh mahasiswa. Beberapa peningkatan yang harus dilakukan meliputi: (1) cara penyajian yang sekarang masih didominasi oleh teks $(80 \%)$ perlu diperkaya dengan ilustrasi baik yang statis (gambar/foto) maupun dinamis (video); (2) cakupan substansi perlu ditambah dengan isu-isu terkini seperti isu terkait SDGs, perubahan iklim, kegiatan manusia, habitat, konservasi, dan pengelolaan kawasan untuk menunjang pembangunan berkelanjutan; dan (3) pendekatan penyajian materi agar multi-displiner dan interdispliner karena ekologi merupakan ilmu pengetahuan yang holistic yang sangat erat kaitannya dengan berbagai bidang ilmu lainnya. Berdasarkan hal tersebut, rancangan matakuliah perlu direvisi agar BA yang dikembangkan mencerminkan perbaharuan-perbaharuan yang diperlukan tersebut.

\section{REFERENSI}

Arsyad, A. (2011). Media pembelajaran. Jakarta, Raja Grafindo Persada.

Dick, W., Carey, L., and Carey, J. O. (2015). The systematic design of instruction (8 $8^{\text {th }}$ Edition). USA: Pearson,

Munir. (2010). Kurikulum berbasis teknologi informasi dan komunikasi. Bandung: Kerjasama Universitas Pendidikan Indonesia dengan CV. Alvabeta.

Suparman, A. (2014). Teknologi pendidikan dalam pendidikan jarak jauh. Solusi untuk kualitas dan aksesibilitas pendidikan. Jakarta: Universitas Terbuka.

Withgott, H. \& Brennan, R. (2007). Environment: The science behind the stories. San Fransisco: Pearson Benjamin Cummings.

(C) 2021 by the authors. Submitted for possible open access publication under the terms and conditions of the Creative Commons Attribution (CC $\quad$ BY $\quad S A)$ license (https://creativecommons.org/licenses/by-sa/4.0/). 